\title{
Una noción de imaginación política a partir de Lavorare con lentezza de Cráter Invertido
}

\section{A Notion of Political Imagination derived from Cráter Invertido’s Lavorare con lentezza}

Artículo recibido el 27 de febrero de 20I8; devuelto para revisión el 2I de agosto de 20I8; aceptado el 27 de agosto de 2020; https://doi.org/IO.2220I/iie.I8703062e.202I.II8.2750.

Mario Alberto Universidad Nacional Autónoma de México, programa de becas posMorales Domínguez doctorales de la UnAM, becario del Instituto de Investigaciones Estéticas, mariomorales@gmail.com, https://orcid.org/0000-0002-2267-1513

Líneas de investigación Teoría de la imagen; arte contemporáneo; diseño; políticas de la creación; estudios culturales y siglo xx.

Lines of research Picture theory; contemporary art; design; politics of creation; cultural studies and 2oth century.

Publicación más relevante "Nietzsche, Heidegger y los maestros de la comedia de la existencia", Theoría. Revista del Colegio de Filosofía, unam, núm. 38 (2020): 57-74.

Resumen El objetivo de este artículo es proponer una noción de imaginación política a partir de una aproximación iconológica de una pieza que ha sido elaborada e identificada como arte político. Parto de una comprensión de la iconología basada en Georges Didi-Huberman la cual se confronta a la obra Lavorare con Lentezza, un dibujo colectivo de $5 \times$ I.2 metros aproximadamente, elaborado por el colectivo mexicano Cooperativa Cráter Invertido, y presentada en la Bienal de Venecia, 20I5. Desarrollo tres apartados que abarcan los momentos de creación, exhibición y recepción de la obra, respectivamente. Al mismo tiempo, hago una definición de imaginación política en consonancia con las referencias y derivaciones que cada momento me permite. Por último, propongo una noción de imaginación política apegada al caso que abordo, pero no exhaustiva, definitiva ni mucho menos excluyente de otras propuestas que pueda haber sobre el tema.

Palabras clave Iconología; Georges Didi-Huberman; arte político; México; dibujo; Bienal de Venecia. 
Abstract The aim of this article is to propose a notion of political imagination
from an iconological approach to a piece that has been elaborated and
identified as political art. I start from an understanding of iconology
based on the ideas of Georges Didi-Huberman to contrast it with the
artwork Lavorare con Lentezza, a collective drawing of approximately
$5 \times$ I.2 meters, produced by the Mexican collective Cooperativa Cráter
Invertido, and presented at the Venice Biennale, 20I5. There are three
sections that include the moments of creation, exhibition and recep-
tion of the work respectively. At the same time, a definition of political
imagination is drawn up in consonance with the references and deriva-
tions that each moment allows us. Finally, a notion of political imagi-
nation is proposed, which is in line with the case dealt with here; this
is not however exhaustive, definitive or even exclusive of other propo-
sals that may exist on the subject.

Keywords Iconology; Georges Didi-Huberman; political art; Mexico; drawing; Venice Biennale. 
DOI: https://doi.org/10.22201/iie.18703062e.2021.118.2750

\author{
MARIO ALBERTO MORALES DOMÍNGUEZ
}

\title{
Una noción de imaginación politica a partir de Lavorare con lentezza de Cráter Invertido
}

Tavorare con lentezza es el título de la obra de arte producida por el colectivo Cooperativa Cráter Invertido, en 2015. La pieza consiste en un formato de $5 \times$ I.2 metros en papel Fabriano blanco de gramaje grueso, sobre el cual se trazaron múltiples dibujos y bocetos en tres colores: amarillo, azul y rojo. Estos dibujos los realizaron los miembros del colectivo, así como personas afines que, durante los días de la producción de la pieza, visitaron la casa que rentaba el grupo en aquel entonces, ubicada en la colonia San Rafael de la Ciudad de México. Debido a la pluralidad de manos que intervinieron en la obra, el estilo de los trazos resultantes es muy diverso. De igual manera, se empleó una gama de instrumentos gráficos tales como marcadores de diferente calibre, pinceles de grosor variable e incluso bolígrafos finos. La obra se hizo en el lapso de unas pocas semanas a gran velocidad para presentarse en la Bienal de Venecia de 20I5, a la cual el colectivo fue invitado por Okwui Enwezor para representar a México con la temática de arte actual. La pieza se montó en una estructura de madera construida al momento del montaje, que consistía en una especie de mesa con una curvatura al centro en forma de protuberancia, que asemejaba un puente. Después de la exposición, el colectivo guardó la pieza en el mismo inmueble donde la trabajó.

Además de la Bienal mencionada, Lavorare con lentezza se ha exhibido en tres ocasiones más. La primera, el 22 de enero de 2016 en el Museo Universitario Arte Contemporáneo, en Ciudad Universitaria, México, como parte del 


\section{DOI: https://doi.org/10.22201/iie.18703062e.2021.118.2750}

foro $Y$ se me vinieron muchas imágenes, el cual se propuso como una reflexión colectiva en torno a la imagen de Julio César Mondragón, un joven estudiante normalista de Ayotzinapa asesinado por la policía mexicana en septiembre de 20I4. La segunda, en 20I7, en una casa llamada Espectro Electromagnético, ubicada frente a la que ocupaba Cráter Invertido; ahí, al igual que en este último espacio, llegaron artistas de todas las disciplinas a lo largo de varios meses. La tercera vez, la pieza se instaló en uno de los pasillos interiores de la primera casa con motivo de la lectura e interpretación que daría como resultado final la elaboración del presente texto. En la Bienal de Arte Contemporáneo de Yakarta, Indonesia, en 2015, poco después de su exhibición en Venecia, se presentaron 45 fotografías con algunos detalles de la pieza, las cuales fueron apareciendo sobre un diagrama de calendario, una por día, durante el tiempo que duró esta otra Bienal.

El 20 de julio de 2018 -última vez que se ha presentado al público la pieza completa- se llevó a cabo una lectura interpretativa con el título "Parlare con lentezza. Clase magistral ante Lavorare con lentezza", y con ese motivo se expuso la obra tanto física como teóricamente, ya que se encontraba almacenada en algún rincón de la casa compartida. La lectura giró en torno a tres ejes principales: I) abrir la discusión sobre los diferentes tipos de interpretación de la imagen, de la obra y de los acercamientos al tema; 2) generar pensamiento o teoría acerca de las prácticas que está llevando a cabo Cráter Invertido y cómo éstas se relacionan con nuestro presente y en el contexto de la Ciudad de México; 3) promover un vínculo con el público abierto en la ciudad y, sobre todo, con las personas cercanas al colectivo, incluyendo a sus propios miembros. Algunos de estos ejes han sido tratados en artículos anteriores sobre la obra de Cráter Invertido. ${ }^{I}$ La lectura, guiada por mí en su mayor parte, estuvo también abierta a la participación de todos los asistentes, entre los cuales había algunos miembros del colectivo. La sesión completa se grabó en audio con el objeto de producir un archivo de investigación acerca de esta obra, pero también del colectivo. El presente trabajo retoma en gran medida los planteamientos que nutrieron al primer eje mencionado arriba, con base en una interpretación iconológica — no panofskiana, sino a partir

I. Véase Mario Morales, "Arte contemporáneo e imaginación política: una aproximación desde la obra del colectivo artístico mexicano Cráter Invertido", Tales, Revista de Filosofía de la Universidad Complutense de Madrid, núm. 7 (2017): 133-139, y Mario Morales, "La poética de lo múltiple a partir del caso Cráter Invertido", Tramas, Subjetividad y Procesos Sociales, núm. 47 (2017): 105-I33. 
de la obra de Georges Didi-Huberman, autor francés contemporáneo enfocado en el estudio de la imagen, que ha rastreado y desarrollado por su cuenta la propuesta teórica e histórica de Aby Warburg, en cierta contraposición con la de Erwin Panofsky.

Vale la pena advertir que Didi-Huberman ha insistido en que el método que Panofsky identificó como iconológico conlleva también una serie de supuestos que no son suficientes para dar cuenta de la profundidad de las imágenes. Con ello, muestra que los tres niveles de interpretación panosfkianos - el preiconográfico, basado en identificar los motivos de la obra; el iconográfico, que advierte el tema; y el iconológico, centrado en interpretar el universo simbólico de la obra ${ }^{2}$ implican también un punto de vista positivista y científico que se queda corto frente al tipo de conocimiento que exige el acercamiento a las imágenes y a las obras de arte. De lo que se trata, para Didi-Huberman, es de ir más allá de la interpretación de la imagen como representación que busca "significados", "alegorías" o "fuentes", 3 como lo haría Panofsky, para perseguir un tipo de pensamiento en imágenes, más vinculado a los métodos de Warburg, es decir, dejar de buscar en la imagen otros referentes que no sean también imágenes. ${ }^{4}$ Todos estos planteamientos sirvieron, en su momento, no sólo como detonantes de una lectura y discusión guiada en torno a la obra de Cráter Invertido, sino que constituyeron una clave para la exploración de la pieza, específicamente a partir de la noción de "imaginación política", la cual atraviesa la teoría que a lo largo de varios años ha desarrollado Didi-Huberman.

Para llevar a cabo esta exploración, hay que señalar en primer lugar que, si bien Didi-Huberman no ha definido nunca de manera directa el concepto de imaginación politica, ha dejado muchos indicios a partir de diversos casos y términos clave que aquí nos servirán de guía. Así, desde su perspectiva, la imaginación por sí misma es ya política, pues se trata de una capacidad creadora que tiene el poder de cuestionar toda visión única de las cosas. Por tanto, relaciona esta noción con todas las manifestaciones de descontento cultural, y se centra primordialmente en su registro artístico o en cualquier modo de expresión imaginística como lo son el cine, video, la fotografía,

2. Erwin Panofsky, El significado en las artes visuales (Madrid: Alianza, 1987).

3. Georges Didi-Huberman, Ante el tiempo (Buenos Aires: Adriana Hidalgo, 2008), 34.

4. Georges Didi-Huberman, La imagen superviviente (Madrid: Abada, 2009), 4IO. 


\section{DOI: https://doi.org/10.22201/iie.18703062e.2021.118.2750}

\section{6}

MARIO ALBERTO MORALES DOMÍNGUEZ

propaganda, entre otras, ya sean profesionales o aficionados. 5 Con base en esta premisa, este autor rastrea una gran cantidad de imágenes en la historia de los últimos siglos — desde algunos Caprichos de Goya, hasta fotografías de mujeres indígenas en Juchitán, Oaxaca, tomadas por Graciela Iturbidecomo muestras de la imaginación política. ${ }^{6}$ La pieza del colectivo mexicano, hay que decirlo, se encuentra también inscrita en un marco político, toda vez que se presentó como parte de una reflexión sobre los acontecimientos de Ayotzinapa, así como de las formas de trabajo y las posiciones ideológicas que lo han caracterizado desde su formación alrededor del movimiento \#YoSoyız2 en México, en 2012.7 En consecuencia, el presente trabajo acerca de la obra Lavorare con lentezza parte de la hipótesis de que es posible configurar una noción de imaginación política a partir no sólo de los planteamientos teóricos de Didi-Huberman, sino más aún, de la aproximación a una pieza de arte que se posiciona en varios sentidos como una obra con carácter político. Se trata, por tanto, de una metodología o modo de aproximación experimental que se va componiendo a la vez que se analiza la obra. Para llevar a cabo este acercamiento desarrollo tres apartados que abordan diferentes aspectos de la pieza y que describo a continuación.

En primer lugar, me aproximo a Lavorare con lentezza en diálogo con una teoría de la imagen aún en composición vinculada en forma directa con algunos de los planteamientos específicos de Didi-Huberman. Así, abordaré la obra en relación con la noción de "gesto", teniendo en cuenta la materialidad y el carácter plástico de la obra en cuestión, ya que se trata de dibujos hechos a mano alzada sobre el soporte. Al explorar los alcances políticos de la gestualidad, se tocará la noción de "supervivencia" vinculada con las posibilidades de la misma pieza en torno a las expresiones plasmadas en ella y la importancia de que sea concebida como imagen y como obra de arte. Para finalizar un primer apartado, aludiré a la noción de "atlas", que Didi-Huberman rescata de Warbug, para abordar la pieza como una suerte de atlas de gestos y supervivencias en correspondencia con el contexto en que fue creada.

Una vez expuestos los criterios después de una lectura iconológica, en términos didi-hubermanianos, en la segunda parte analizaré la pieza, iniciando

5. Georges Didi-Huberman, Supervivencia de las luciérnagas (Madrid: Abada, 20I2).

6. Georges Didi-Huberman, Sublevaciones (Ciudad de México: Museo Universitario Arte Contemporáneo, 2018).

7. Esto ya fue descrito en Morales, "La poética de lo múltiple a partir del caso Cráter Invertido". 
por el título, con base en los referentes ideológicos particulares de los miembros del colectivo, de su investigación y posición respecto de su participación en la Bienal. A partir de la decisión sobre el nombre que se le dio a la pieza me acerco a ella tanto en el aspecto conceptual como en el de sus características materiales. Sobre todo, planteo que la elección del título trata de darle sentido a la obra en su contexto y en sintonía con las posturas del colectivo en torno a la posición del artista hacia la institución del arte y cómo se puede aprovechar en todo momento para detonar ejercicios de imaginación colectiva y política.

En un tercer y último apartado analizo la cuestión de si se trata de una obra política o no. En un primer momento me remitiré a algunas opiniones de figuras destacadas en el ámbito del arte en México, quienes de manera general desacreditaron la pieza, sobre todo en lo que respecta a su potencia política y lo que se esperaba del colectivo. Sin embargo, en un segundo momento demostraré cómo la pieza responde desde su estructura ya no sólo como gesto, supervivencia, atlas o título, sino como materialización de una asamblea como ejercicio político por excelencia. Así, se constatará que la obra se sostiene como una manifestación política en cuanto a la expresión de formas de operar que tienen que ver con los procesos asamblearios, así como con nociones rescatadas de los debates contemporáneos en teoría política tales como la militancia alegre y la imaginación radical.

Así, mi análisis de la pieza es una aproximación política de la imaginación. Los apartados arriba descritos pueden leerse también como tres momentos de la obra: creación, exhibición y recepción. De esta forma, si el primero aborda la gestualidad inscrita en ella, junto con lo que esta acción conlleva y cómo se muestra; el segundo se enfoca en el contexto específico para el que fue pensada y dirigida teniendo en cuenta una posición bien definida; y, por último, en el tercer apartado se describe lo que pasó después y por qué la pieza es política en ese aspecto, lo que me da las últimas pautas para la noción de imaginación política que quiero construir. De este modo, en la conclusión brindaré un esbozo de lo que podría significar una imaginación política en referencia a lo que se fue extrayendo de la pieza. Este intento va desde la selección de pistas clave sobre las cuales transitar, hasta las raíces y visiones para construir un futuro posible para las prácticas, relaciones, comunidades, movimientos y afectos involucrados; ya no sólo al interior del colectivo que aquí estudio, ni en cuanto al abordaje de obras de arte, sino sobre todo hacia el exterior de la esfera artística, hacia el ámbito de la política y de nuestro presente (fig. I). 


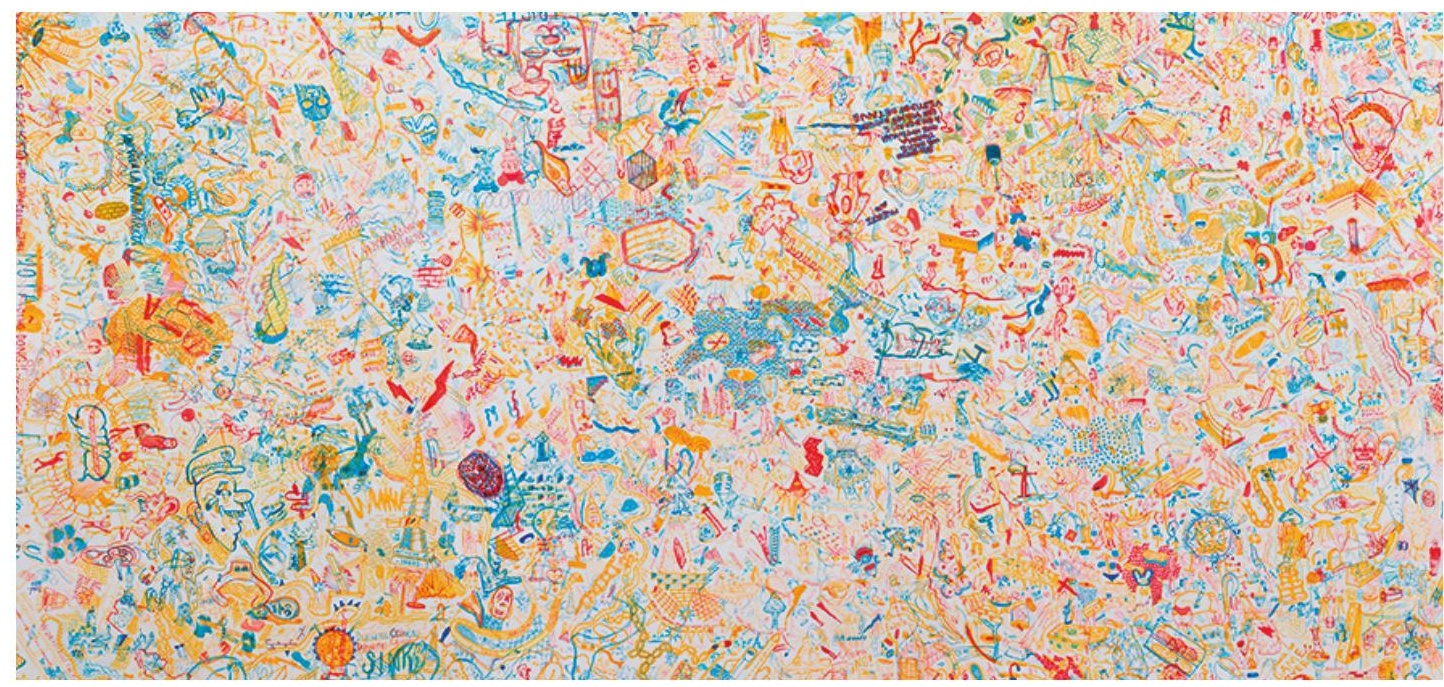

I. Cooperativa Cráter Invertido, Lavorare con lentezza, 2015, escala I:33 aprox., Ciudad de México. Cortesía del colectivo.

\section{Gestos-creación}

En la obra se encuentran caricaturas, líneas a manera de textura, plastas de color, figuras informes, dibujos más o menos realistas, textos sin sentido, poemas cortos, consignas, simplemente trazos o letras sueltas, entre otros elementos. Todo esto en formas orgánicas, geométricas y accidentales. De igual manera se podrían enumerar diversos motivos como: sillas, policías, montañas, fantasmas, corazones, máscaras, billetes, tabiques, redes, túneles, torbellinos, telarañas, nopales, serpientes, escaleras, nubes, hongos, casas, torres eléctricas, alambres de púas, pistolas, automóviles, megáfonos, molcajetes, pirámides, clavos, cadenas, huaraches, aguacates, plátanos, trenzas, aros, anillos, botellas, sombreros, paraguas, frijoles, cruces, sándwiches, hot dogs, papas fritas, llantas ardiendo, monedas, licuadoras, rejas, cuerpos enteros o sus partes como manos, ojos, brazos, piernas, brazos o pies, animales como perros, cerdos o monos, símbolos e iconos de todo tipo, entre muchas otras figuras con o sin forma definida. Sería difícil extraer una referencia común a todos estos objetos a excepción quizá de que pertenecen a la cultura y la vida cotidiana actual. La forma del trazo podría englobarse en el dibujo o boceto sin la 


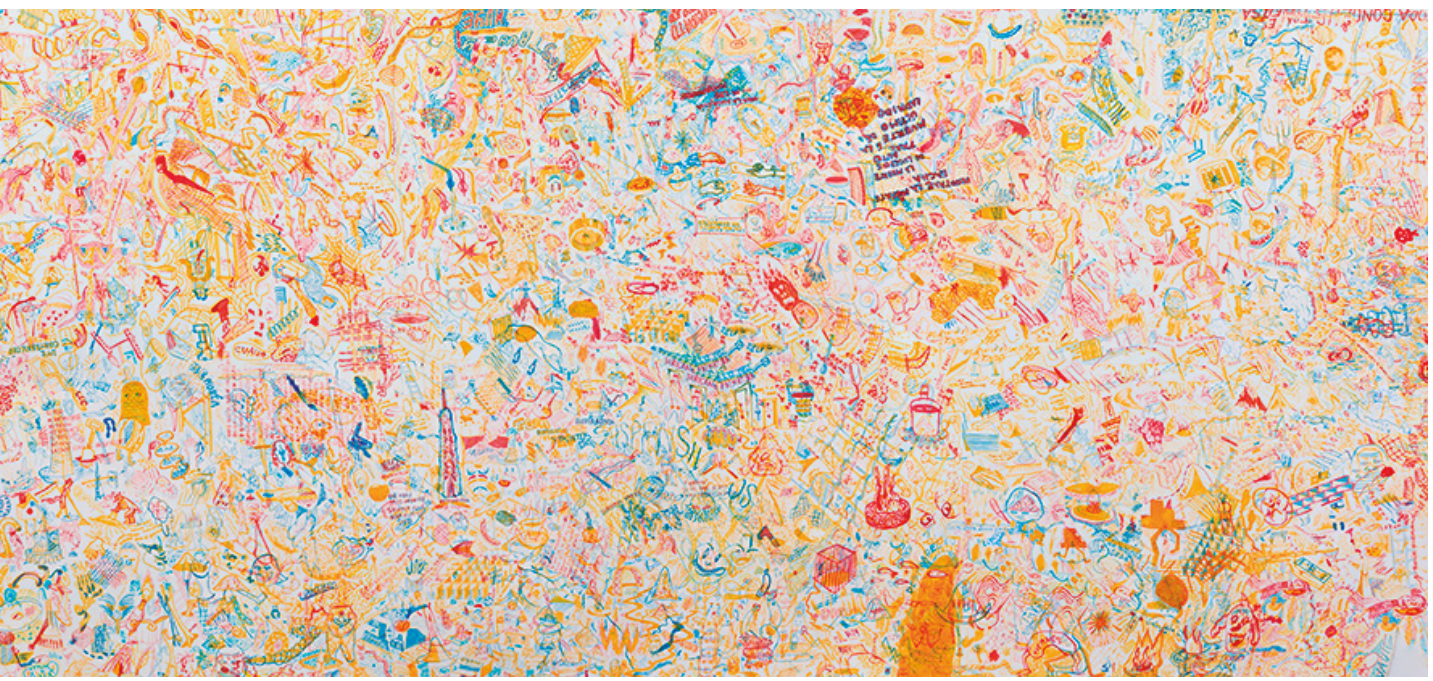

asistencia de instrumentos de precisión de medida más allá del ojo. El resultado es una suerte de ilustración a manera de garabatos muchos de los cuales adquieren la forma de caricaturas sencillas, imitaciones extraídas de la cultura pop, pero también de diagramas o esquemas estereotipados de dibujo como fantasmas, telarañas o casas. Muchas veces los dibujos se copian o emulan unos a otros dentro del mismo espacio, se componen por capas que en ocasiones se estorban, se yuxtaponen, se complementan, se desvían o se mezclan usando los tres colores que la caracterizan. Una descripción exhaustiva de la obra requeriría demasiado espacio textual, tan sólo nombrar y pormenorizar los detalles que la componen podría ocupar páginas y páginas. Pero más allá de un acercamiento meramente iconográfico, la pieza se presta también para la observación de algo que no puede ser traducido a palabras. Se trata entonces de una lectura iconológica donde las imágenes nos puedan decir algo más, no sólo del contexto en el que fueron producidas, sino también del nuestro y de nuestra capacidad para interpretarlo.

En un primer momento, habría que advertir que a lo que nos enfrentamos con la obra Lavorare con lentezza, más allá de una simple aglutinación de motivos, es a la esfera de la pura gestualidad. Se trata de algo que, aunque pueda contener letras, palabras o frases, se sitúa sobre todo en un nivel intermedio entre el mero hecho de colocar cualquier objeto capaz de dejar una marca sobre un sustrato, y la articulación de un movimiento consciente para 


\section{DOI: https://doi.org/10.22201/iie.18703062e.2021.118.2750}

IOO

MARIO ALBERTO MORALES DOMÍNGUEZ

que el trazo adquiera un sentido o significado. El gesto está relacionado con los movimientos espontáneos y no planeados del cuerpo, que se hacen visibles en el momento en que se rompe un determinado régimen normalizado del comportamiento humano. Los gestos definen una cierta singularidad de las personas y se hacen patentes solamente en relación con los de sus congéneres. Nos muestran la afinidad que compartimos en referencia a lo humano, pero al mismo tiempo, expresan la diferencia particular de cada uno. "El hecho de que no dominemos totalmente los gestos significa que no los hemos perdido (o que no nos han abandonado). Los gestos transmiten, los gestos sobreviven pese a nosotros mismos y pese a todo." ${ }^{8}$ Los gestos podrían interpretarse como fósiles vivientes dentro de nosotros, movimientos inconscientes que han sido heredados generación tras generación y que nos hablan de nuestra cultura en una larga duración. Observar los gestos es realizar una labor antropológica, en particular relacionada con el deseo y sus manifestaciones, diría Didi-Huberman. ${ }^{9}$

El gesto, además, tendría una potencia política. $\mathrm{Al}$ expresarse como rasgos distintivos cada vez, nos hablan de la pluralidad de posiciones o reacciones que pueden existir ante cualquier intento por generalizar las potencialidades humanas. Los gestos muchas veces se pasan por alto al considerarse algo efímero o insustancial. Pero hay ocasiones en que uno solo puede convertirse en un acto político que detone un movimiento, por ejemplo. Sobre todo, si se manifiesta como respuesta a una imposición autoritaria o a una regla establecida de las buenas maneras sociales, entonces adquiere una dimensión subversiva. En ese sentido, el gesto siempre resiste. No obstante, para que su modo de rebeldía tenga fuerza, es necesario que ésta genere efectos de algún tipo y tenga la posibilidad de expandirse o diseminarse. Si el gesto logra trascender el primer estrato para no sólo hacerse visible, sino también pervivir y provocar secuelas en cualquier sentido, entonces se convierte en huella. Puede ser un mero registro físico o mental, pero, en cualquier caso, la huella es un gesto grabado. $\mathrm{Si}$ éste nace como una singularidad, una distinción, en el curso actual del mundo, la huella tiene la capacidad de virar por completo la dirección del mismo. Se trata de la marca de una fuerza que permanece y atraviesa el tiempo como supervivencia. Por eso, siguiendo la interpretación de Didi-Huberman, ${ }^{\text {,o }}$ el ges-

8. Didi-Huberman, Sublevaciones, 28.

9. Didi-Huberman, Sublevaciones.

Io. Didi-Huberman, Sublevaciones. 
to podría verse como una forma primaria de oponerse a una lectura única de la historia. Y, por su parte, la huella permitiría dar cuenta de que más allá de cualquier cronología, hay algo que nos sobrevive siempre. La sucesión temporal o la linealidad del tiempo se rompe con la huella. No sólo, como lo ha destacado Jacques Derrida, la huella, al poder haber estado ahí desde antes de nuestro nacimiento y tener la capacidad para sobrevivirnos, nos confronta con nuestra propia muerte; ${ }^{\text {II }}$ recordándonos nuestra finitud. También, recuperando el trabajo que Didi-Huberman le ha dedicado al historiador del arte Aby Warbug, la huella nos habla de la supervivencia. ${ }^{\text {I2 }}$

¿Qué es lo que sobrevive en una pieza como Lavorare con lentezza? Al tratarse de una obra en la que participaron varias personas, tanto internos al grupo como externos al mismo, lo que queda grabado son pulsos diversos, manos y subjetividades dispares unas con otras que conviven, o que al menos coexisten, en un mismo plano. El dibujo se produjo materialmente en la casa que el grupo Cráter Invertido ha destinado para sus proyectos, y que rentó desde principios de 2014 hasta agosto de 20I9. Pudieron disponer de este inmueble durante ese tiempo, y lo siguen haciendo — aunque en una nueva sede — hasta el momento en que este texto está siendo escrito, gracias a una beca obtenida por Arts Collaboratory, una organización que se describe a sí misma como: "Un ecosistema translocal de veinticinco organizaciones localizadas en África, Asia, América Latina, el Medio Este y Países Bajos que está enfocada en prácticas artísticas, procesos de cambio social y trabajo con comunidades más allá del campo del arte." ${ }^{13}$ La organización sigue una serie de principios que utilizan como lenguaje común todos los suborganismos que la conforman, tales como afinidad, apertura, trabajo colectivo, autocuidado, descentralización, autoorganización, ética, hospitalidad, micropolítica, mutualismo, solidaridad, estudio, confianza e imaginación radical, entre otros. ${ }^{14} \mathrm{Si}$ bien estos principios se comparten con otros grupos alrededor del mundo, en Cráter Invertido adquieren su

II. Jacques Derrida, La escritura y la diferencia (Barcelona: Anthropos, 1989).

I2. Didi-Huberman, La imagen superviviente.

I3. Traducción del original: "Arts Collaboratory (AC) is a translocal ecosystem of twenty-five organizations situated in Africa, Asia, Latin America, the Middle East, and the Netherlands that is focused on art practices, processes of social change, and working with communities beyond the field of art.", en Arts Collaboratory, "Home", consultado el I9 de febrero de 2020, en www.artscollaboratory.org/.

I4. Arts Collaboratory, "Common Language", consultado el 9 de diciembre de 20I8, en www.artscollaboratory.org/. 


\section{DOI: https://doi.org/10.22201/iie.18703062e.2021.118.2750}

IO2

MARIO ALBERTO MORALES DOMÍNGUEZ

propio matiz. El ambiente que rodea a la casa que rentaba el colectivo en la colonia San Rafael, cerca del Centro de la Ciudad de México, irremediablemente interpelaba a todo aquel que visitaba el lugar. Se trata de una zona popular cercana a la estación San Cosme del transporte subterráneo colectivo Metro. Tan sólo en el corto trayecto de la estación a la casa de Cráter Invertido, ${ }^{15}$ se pueden encontrar infinidad de objetos de muy diversas procedencias, así como tiendas de conveniencia pertenecientes a cadenas multinacionales, negocios locales y puestos callejeros organizados en una especie de minitianguis que conviven entre sí y ofrecen productos industriales y no industriales de distintas épocas y destinados a múltiples usos. Por ejemplo, se vende ropa interior femenina, al lado de cables y demás implementos electrónicos —algunos pirata-, antojitos mexicanos conocidos como "garnachas", servicios de peluquería, comida corrida, pulque, tacos, entre otros. De modo que quienes visitaban el Cráter, que resultaba una especie de guarida del arte en contraste con el indómito y carnavalesco exterior, habían pasado ya por esa fuerte experiencia sensorial que, en definitiva, repercutía en lo que plasmaban en la obra.

La supervivencia, siguiendo a Didi-Huberman, abre otro tiempo distinto al contemporáneo. Es éste un concepto extraído de los escritos de Warburg, de principios del siglo xx. La supervivencia plantea la posibilidad de un tiempo estructurado a partir de múltiples pasados entretejidos, que se manifiesta en lo minúsculo, superfluo, irrisorio o anormal. ${ }^{16}$ Lo anacrónico, como aquello que ofrecen los puestos callejeros, es un cobijo para la supervivencia. Constituye un síntoma de desorientación temporal que nos da la posibilidad de transportarnos a otros lugares y épocas con el simple acto de la mirada. ¿Qué es lo que sobrevive sino los rastros de la vida misma, rastros del movimiento, huellas? Estas últimas pueden interpretarse como señales de que alguna vez hubo algo diferente. En ese sentido, la supervivencia rompe con la homogeneidad de la historia. Es algo indefinido que va más allá de la vida biológica. Lo que sobrevive es la imagen como fuerza genealógica, dice Didi-Huberman a propósito de Pierre Fédida. ${ }^{17}$ Es decir, no es sino gracias a las imágenes que han quedado grabadas en documentos de todo tipo, desde productos populares hasta obras de arte, que podemos imaginar otros mundos posibles; otras formas de leer la historia, nuestro presente y pasado. En última instancia, la obra de la que

15. En adelante simplemente "Cráter" para diferenciar el lugar del nombre del colectivo.

16. Didi-Huberman, La imagen superviviente, 50.

17. Georges Didi-Huberman, Gestos de aire y piedra (Ciudad de México: Canta Mares, 2017). 
estamos dando cuenta aquí, Lavorare con lentezza, no es sino un conglomerado de experiencias, impresiones y sensibilidades plasmadas en un soporte bidimensional que, una vez que han sido expulsadas del cuerpo que las alberga, ya no le pertenecen a éste, sino a quien mira el resultado.

Hablar de autor o autores ante una obra como ésta se vuelve problemático, pues los mismos miembros de Cráter Invertido parecen haber tenido la intención de borrar esta figura del imaginario que rodearía la pieza. El mismo colectivo ha variado de miembros y es difícil encontrar en la casa a las mismas personas cada vez. El Cráter es un lugar transitado por personajes diversos donde, al menos actualmente, es raro ver a los miembros "oficiales" del grupo. Lavorare con lentezza es un reflejo de esta dinámica en la que no hay una voz o un trazo que sobresalga por encima de los otros. Está ahí para operar no como una composición bien organizada con jerarquías y órdenes fijos, sino tan sólo como una imagen, en el sentido de una huella del movimiento. Las imágenes, ya sean materiales o mentales, pueden ser visuales, acústicas, olfativas, gustativas o táctiles. En esta ocasión cobró la forma de una gráfica que es relevante en cuanto a su plástica o al contenido semiótico de sus dibujos y textos, y también por las derivaciones políticas con que conscientemente se concibió, evadiendo cualquier posibilidad de una lectura única de la pieza. La obra ha sido planteada por los miembros del colectivo como una especie de atlas ${ }^{18}$ haciendo referencia precisamente a los trabajos de imaginación del historiador del arte Warburg. Se trata, en este caso, de un atlas de sensibilidades y gestos políticos.

En su pluralidad, todos los trazos del dibujo componen un mapa, una especie de cartografía de lo sensible que da cuenta del entorno particular en el que se produjo. Pero no sólo eso, estos gestos materializados, toda vez que fueron reunidos casi azarosamente dentro de un marco rectangular limitado, quedan ahí para ser leídos por quien sea en el futuro. Puesto que han sido trazados unos junto con otros o unos sobre otros, no hay forma de que se les contemple y menos aún se les interprete por separado. No hay modo de que en ellos se busque a un solo autor o una sola intención. Cada marca, cada línea, cada bosquejo está destinado a ser visto en relación con los otros. Esto podría debilitar su presencia como elementos individuales, pero permite potenciarlos en

I8. Andrés Villalobos, "Políticas y poéticas del arte participativo en México", entrevista con Nina Fiocco, Museo Amparo, Puebla, 29 de marzo de 2017, I:36:32, consultado el 25 de febrero de 202I, www.youtube.com/watch?v=dXgeuSZVF_o. 


\section{DOI: https://doi.org/10.22201/iie.18703062e.2021.118.2750}

IO4

MARIO ALBERTO MORALES DOMÍNGUEZ

el conjunto. Como lo diría Didi-Huberman, con las imágenes pasa lo mismo que con las palabras. Así como una palabra aislada no dice nada, sino que sólo adquiere sentido frente a otras palabras y en el contexto en que es emitida, de igual modo las imágenes adquieren fuerza y significado en diálogo con otras. ${ }^{19}$ Así pues, no es ninguna casualidad, como se verá más adelante, que deban disputarse su espacio de esa manera. Como se señaló antes, esas imágenes son el resultado de un ejercicio colectivo del que aún debemos sacar provecho como lectores. "Las imágenes, como las palabras, se blanden como armas y se disponen como campos de conflictos. Reconocerlo, criticarlo, intentar conocerlo con la mayor precisión posible: ésa es tal vez una primera responsabilidad política cuyos riesgos deben asumir con paciencia el historiador, el filósofo o el artista." ${ }^{20}$

El atlas, como objeto editorial constituido por páginas de imágenes, es una figura conceptual que Didi-Huberman retoma del trabajo que Warburg desarrollaba los últimos ańos de su vida. El Atlas Mnemosine, como proyecto inconcluso de Warburg, ha dado la oportunidad al autor francés para explorar las potencialidades de este tipo de publicaciones, al tiempo que especula sobre los objetivos y posibles resultados a los que pudo haber llegado el historiador alemán. Uno de los rasgos que más destaca Didi-Huberman de un atlas es que se presta a una lectura no lineal o única. Al estar constituido por imágenes, nos invita a hacer nuestra propia lectura. Podemos saltar las páginas de un libro de esta naturaleza dejándonos llevar sólo por la mirada, sin atender al discurso, argumento o narración alguna que dirija nuestra aproximación. Tal es la propuesta iconológica que planteo en este trabajo, tomando en cuenta, al mismo tiempo, que el nombre de Atlas nos recuerda al titán que en la mitología griega fue castigado por retar a los dioses del Olimpo. De acuerdo con este relato, una vez que los titanes fueron vencidos, Atlas fue condenado a sostener el cielo separado de la tierra por toda la eternidad. Para Didi-Huberman, la imagen de este personaje mitológico es también una representación de la figura del artista, quien al darle sentido, carga sobre sus hombros al mundo entero. ${ }^{21} \mathrm{El}$ atlas

19. Georges Didi-Huberman, "Yo no sé lo que es el arte", entrevista con Cecilia Macón, $\mathrm{La}$ Nación, 3I de octubre, 20I4, consultado el 25 de febrero de 202I, en https://www.lanacion.com. ar/I739946-georges-didi-huberman-yo-no-se-lo-que-es-el-arte.

20. Georges Didi-Huberman, Pueblos expuestos, pueblos figurantes (Buenos Aires: Manantial, 2014), I9.

2I. Georges Didi-Huberman. Atlas ¡cómo llevar el mundo a cuestas? (Madrid: Museo Nacional Centro de Arte Reina Sofía, 2010). 
entonces, como modo de acercamiento a las obras, conlleva una responsabilidad particular. No hay curso de lectura único ni final, se trata de una composición de rutas inexploradas, que parten de los gestos inscritos ahí, pero que nos pueden llevar a cualquier lugar. En el caso de Lavorare con lentezza, el esfuerzo evidente por respetar la esfera de la gestualidad, al dejarla prácticamente al desnudo frente a la mirada, nos invita a llevar a cabo este ejercicio de composición personal ante la obra. Sin embargo, la pieza no está sola, dado que una imagen nunca se produce o se percibe de manera aislada. Si tomamos en cuenta el acercamiento iconológico que propone Didi-Huberman, el contexto en el que se inscribe, tanto en el momento de su creación como en el de su mantenimiento y recepción, forma parte de lo que Lavorare con lentezza tiene que decirnos. En el siguiente apartado abordaré la obra en su situación, sobre todo a partir del título que el colectivo decidió asignarle (fig. 2).

\section{Situación-exhibición}

$\mathrm{Al}$ igual que el acercamiento que hicimos a los dibujos, habría dos formas de abordar el título de la pieza: como la descripción de lo que tenemos que ver en ella o como una extensión de un mismo gesto político. La primera podría llevarnos a interpretar el título de manera literal, como si se tratara de una especie de imperativo en su traducción al español "trabajar con lentitud". Sin embargo, es necesario desplegar en todas sus dimensiones esta proposición, pues tal como se presenta, en italiano, parece no decirnos mucho acerca de los motivos observables en el soporte de papel. Es cierto, por un lado, que la frase "lavorare con lentezza" aparece entrecortada en la pieza. Se alcanza a leer "Lavo... con lentezz..." en medio de otras tantas leyendas tales como "En México no hay democracia", "Un poco de engaño en lo trágico, una pisca de juego en lo común", ${ }^{22}$ "Dibujitos críticos", "el ano nos une", "Debut y despedida", "Los saldos de la década perdida", "el rumor del incendio", "somos criminales", "soy bien racista", "burocracia prematura", "estamos en el hoyo", "explota lo que te explota", "casi muerto" o "viva la anarquía”. También se lee una especie de poemas cortos o pronunciamientos como "Sólo quiero una noche tranquila, que no vengan a

22. La errata ortográfica en la palabra "pizca" se encuentra así en la pieza. Esto parece ser una paráfrasis de un aforismo de Émile Cioran (Del inconveniente de haber nacido [Madrid: Taurus, I998], 48). 
DOI: https://doi.org/10.22201/iie.18703062e.2021.118.2750

106

MARIO ALBERTO MORALES DOMÍNGUEZ

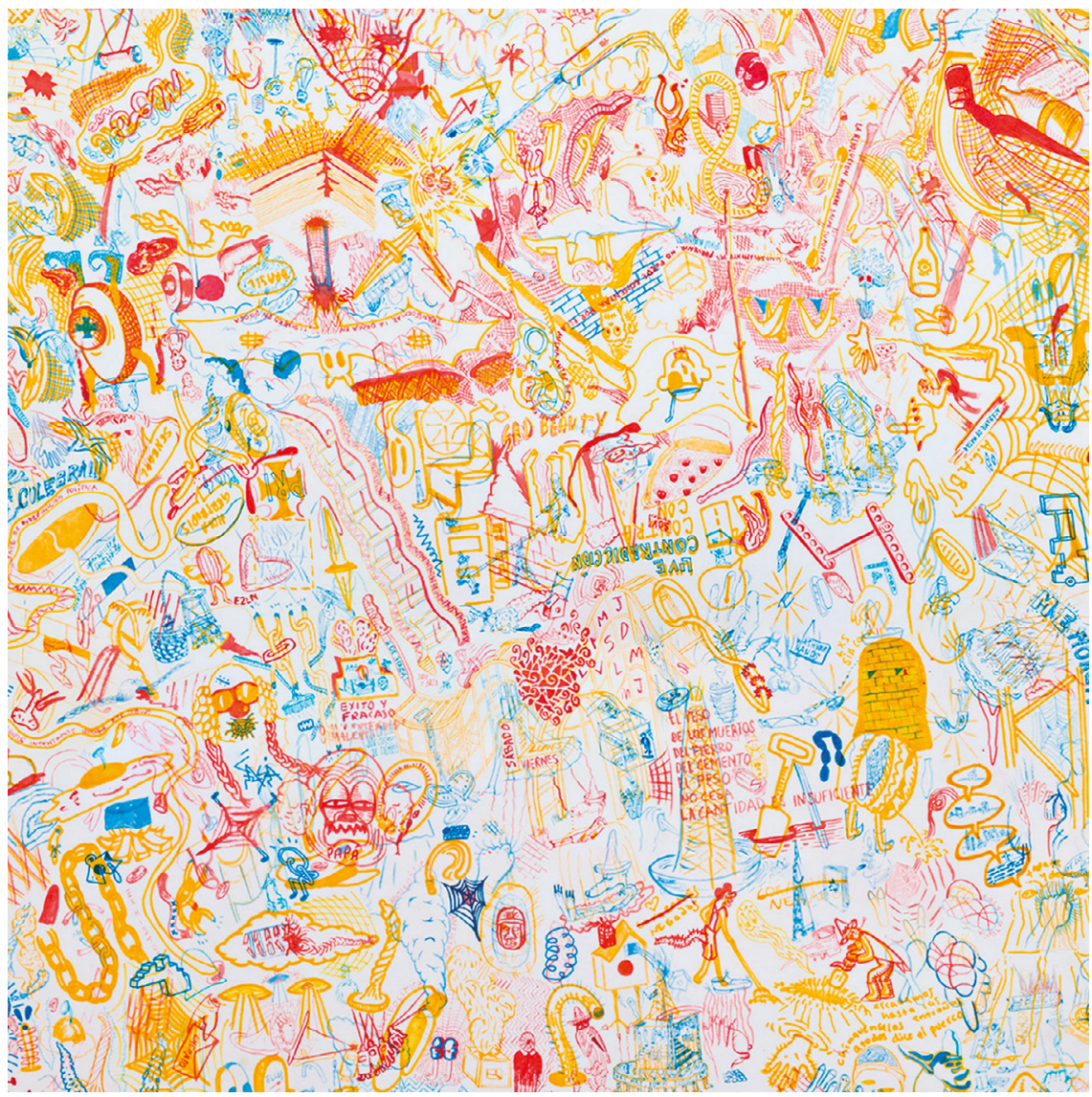

2. Cooperativa Cráter invertido, Lavorare con lentezza (fragmento), 2015, escala I:5 aprox., Ciudad de México. Cortesía del colectivo.

golpearme los viejos amigos vestidos de traje", "El peso de los muertos, del fierro del cemento, el peso no cesa. La cantidad es insuficiente", "¿Quién no quiere dinero? ¿dime quién no quiere dinero?”; junto a una gran cantidad de palabras sueltas como "nosotros", "azul”, "amarillo”, "lunes”, "viernes”, "sábado”, "hoy”, "ayer", "siempre”, "impuntuales", "barricada”, "desaparecido", "sabotaje”, "memoRÍA"; y algunas frases en otros idiomas, como "I'm not exotic, I'm exhausted", ${ }^{23}$

23. Esta frase hace referencia, entre otras cosas, al título de una exposición de graffiti de Dan Perjovschi, llevada a cabo en Basilea, Suiza, en 2008. 
"le parfum du tiers monde", "suicidati dallo stato", o combinaciones como "utopía o game over", "live contradicción”, entre muchas otras. Varias de estas leyendas están en diálogo con los dibujos de manera muy evidente, algunas no tanto y otras lo están por completo en otro plano. Sin duda sería posible reconocer un contenido político en la conjunción de todas estas leyendas. Además, un texto largo, con consignas similares a las ya mencionadas, pero sin un único sentido coherente, rodea toda la pieza, como si fuera una especie de marco interior. No obstante, no se logra ver en el conjunto alguna orientación directa al título Lavorare con lentezza, al menos no en lo que alcanza a entenderse debido al tamaño, la calidad caligráfica y la superposición de elementos que en toda la superficie de la obra impiden en muchos momentos seguir las inscripciones textuales. Quizá podría leerse el título como una descripción de la forma en que fue realizada la pieza, es decir, a lo largo de muchas horas de trabajo, sin embargo, en el contenido no encontramos pista alguna que nos pueda guiar hacia el empleo del idioma extranjero. Esto último más bien llama a una lectura de la obra en su situación, en torno al lugar para el que fue pensada y en el que fue exhibida, la Bienal de Venecia. Para poder establecer un puente en este apartado, será necesario remitirnos a los referentes del título independientemente de la pieza para luego atenderlos en función de ella, esto es, como aquellos elementos que extienden la operación política que ejerce la obra en la situación en la que se inscribe.

Más allá de su significado textual, el título nos remite a dos cuestiones. Por un lado, Lavorare con lentezza es el nombre de una película italiana de 2004, dirigida por Guido Chiesa. La trama del filme de ficción se basa en los hechos reales ocurridos alrededor de Radio Alice, una emisora pirata de los años setenta. Estas emisoras clandestinas se infiltraban en las señales de las estaciones comerciales, para generar sus propias señales de forma casera. En Italia, esta radiodifusora estaba políticamente vinculada con el movimiento autonomista (también conocido como obrerista u operaísmo), de carácter marxista-anarquista. Algunos personajes importantes vinculados con ese movimiento hoy se han vuelto referencias de la teoría política contemporánea, tales como Antonio Negri, Mario Tronti o Franco Berardi Bifo. Félix Guattari, por su parte, lo registra de la siguiente manera:

En Bolonia, todo comenzó con no más de cien personas, tratando de imaginar qué hacer. Radio Alice catalizó un proceso, algo, no exactamente algo que tuvieran en común, pero es difícil saber describirlo de otra manera. Sí, un proceso en marcha en todas las diversas autonomías: estudiantes, feministas, homosexuales, trabajadores 


\section{DOI: https://doi.org/10.22201/iie.18703062e.2021.118.2750}

IO8

MARIO ALBERTO MORALES DOMÍNGUEZ

migrantes del sur. Entonces comenzaron a producirse grandes desarrollos en los movimientos de autorreducción y apropiación, rechazo al trabajo, ausentismo, etc. En 1976, Bifo, uno de los espíritus en movimiento de Radio Alice, fue arrestado por "revuelta por instigación moral" ${ }^{24}$

En la película se muestra a un conjunto de jóvenes que se organizan de manera un tanto caótica, pero jubilosa. Por supuesto, esos muchachos se enfrentan también a todo tipo de discrepancias dentro del grupo, como cualquier colectivo, sumadas a los obstáculos que les ponen las autoridades y a sus esfuerzos por mantenerlos vigilados y a raya. Esta situación que muestra la película atraviesa las dinámicas que suelen presentarse en todo tipo de colectivos juveniles que intentan organizarse para transformar la realidad en la que viven, como es el caso de Cráter Invertido evidentemente. Se trata de una cuestión de afectos y de políticas intragrupos, de arreglos interpersonales, cuestiones íntimas y corporales, de choques de ideas, pero también de hábitos, costumbres o simples gestos. Cuando todos estos elementos se ponen en suspenso, lo que parecieran de sentido común, entonces se está haciendo micropolítica, o como lo definiría Guattari: revolución molecular. Más adelante, en el último apartado, volveremos con mayor detenimiento sobre la forma en que se organiza Cráter Invertido en su interior, pero por ahora sólo quisiera establecer el paralelismo, quizá no casual, entre aquella coyuntura representada en la cinta cinematográfica y las situaciones comunes con el colectivo en cuestión.

Por otro lado, Lavorare con lentezza también es el nombre de una canción de 1974, del cantautor Enzo Del Re, figura reconocida de la música de protesta desde los años setenta. El título de la película de 2004, de hecho, hace referencia a esta obra musical, pues servía como tema de apertura y cierre de las emisiones de Radio Alice. La pieza está cantada casi a capella, tan sólo la acompaña el sonido de una silla usada a manera de percusión. Este sencillo recurso no es fortuito, pues constituye también un gesto político musical. El ritmo

24. "In Bologna it all began with no more than a hundred people, trying to work out what to do. Radio Alice catalysed a process, something — not exactly something they had in common, but it is hard to know else to describe it. Yes, a process at work in all the various autonomies - school students, feminists, homosexuals, migrant workers from the south. Then there began to be great developments in the movements of self-reduction and appropriation, refusal to work, absenteeism, etc. In 1976, Bifo, one of the moving spirits in Radio Alice, was arrested for 'morality instigating revolt", en Félix Guattari, Molecular Revolutions: Psychiatry and Politics (Londres: Puffin, 1984), 238 (la traducción es mía). 


\section{DOI: https://doi.org/10.22201/iie.18703062e.2021.118.2750}

UNA NOCIÓN DE IMAGINACIÓN POLÍTICA

y la tonada repetitivos se perciben como una especie de antihimno del trabajo. Paralelamente al arte povera, Del Re elige este tipo de recursos elementales para transmitir su mensaje. La letra completa de la canción dice:

Trabaja despacio sin hacer esfuerzo, quien es rápido se lastima y termina en el hospital. En el hospital no hay lugar y puedes morir pronto. Trabaja despacio sin hacer esfuerzo, la salud no tiene precio, así que reduce la velocidad. Pausa pausa, ritmo lento, pausa pausa, ritmo lento, siempre fuera del motor, vivir en cámara lenta.

Trabaja despacio sin hacer esfuerzo.

Te saludo, te saludo con un puño cerrado.

En mi puño está la lucha contra la nocividad.

Trabaja despacio sin hacer esfuerzo.

Trabaja despacio.

Trabaja despacio.

El trabajo masacrante existe porque los sueldos y las labores no están distribuidas equitativamente. Amo trabajar, pero detesto el cansancio. ¿Qué es el cansancio? El cansancio es ese dolor físico que se opone a la continuación del trabajo. Yo no quiero hacer nada para los explotadores. ¡Por la clase trabajadora, a la que me siento honrado de pertenecer, yo estoy dispuesto a sacrificar mi vida, pero por los jefes no quiero hacer un carajo! ${ }^{25}$

Las últimas líneas son recitadas y pueden cambiar de acuerdo con el contexto en el que la melodía se ejecuta en vivo, haciendo referencia o burla a situaciones

25. "Lavorare con lentezza senza fare alcuno sforzo / chi è veloce si fa male e finisce in ospedale / in ospedale non c'è posto e si può morire presto / Lavorare con lentezza senza fare alcuno sforzo / la salute non ha prezzo, quindi rallentare il ritmo / pausa pausa ritmo lento, pausa pausa ritmo lento / sempre fuori dal motore, vivere a rallentatore / Lavorare con lentezza senza fare alcuno sforzo / ti saluto ti saluto, ti saluto a pugno chiuso / nel mio pugno c’è la lotta contro la nocività / Lavorare con lentezza senza fare alquno sforzo / Lavorare con lentezza / Lavorare con lentezza. I lavori massacranti esistono perchè i pesi e i compiti non sono equamente distribuiti. Adoro il lavoro, ma detesto la fatica. La fatica che cosa è? La fatica è quel dolore fisico che si oppone alla continuazione del lavoro. Io per gli sfruttatori non voglio fare niente, per la classe lavoratrice, alla quale mi onoro di appartenere, sono disposto a sacrificare la mia vita, ma per i padroni non voglio fare un cazzo!", en Enzo Del Re, Lavorare con Lentezza, Enzo Del Re, CP o02, Italia, 1974 (la traducción es mía). 


\section{DOI: https://doi.org/10.22201/iie.18703062e.2021.118.2750}

IIO

MARIO ALBERTO MORALES DOMÍNGUEZ

políticas específicas. La composición en su totalidad se levanta como una suerte de manifiesto no sólo contra el trabajo forzado y la explotación capitalista, sino también contra la premura de la vida en una sociedad de exigencia constante, de economía inestable y demandante, ávida de novedades y modas pasajeras. Ante ello, es el cuerpo el que responde, como bien lo indica la canción. El cuerpo enferma, lo que se manifiesta con el cansancio, e interpela con su propio ritmo. En español el vocablo italiano lavorare se puede vincular directamente por sus raíces compartidas con la palabra "labor", que ha mantenido el mismo significado de tarea o trabajo. Más aún, con términos como "labrar" o "labranza", en los que permanece el vínculo con el trabajo manual y la capacidad para incidir o transformar la tierra con la acción sobre ella. Pero también tenemos el término "trabajo", por lo común usado para referirse a las labores cotidianas remuneradas y que sirven como sustento individual y colectivo de la sociedad actual. "Trabajo" etimológicamente está enraizado en el vocablo "tripalium", que denomina un instrumento de tortura compuesto por tres maderos a los que se ata un reo para ser azotado. Como se puede ver, al menos en el español, por más que se pueda disfrutar del trabajo, éste nunca deja de contener una carga de suplicio.

Así, con el título Lavorare con lentezza, Cráter Invertido hace referencia a todos estos elementos. Y, una vez que los hemos rastreado, es evidente que el colectivo propone también una autocrítica acerca de su quehacer en esta pieza. Trabajar con lentitud, al tratarse de una obra realizada a mano alzada y sin ayuda de aparato de movimiento alguno, describe perfectamente el esfuerzo realizado por los participantes para configurarla, como ya se había adelantado. Al mismo tiempo, se vuelve también una crítica por medio de la ironía, pues de hecho ellos se vieron obligados a trabajar a marchas forzadas para terminar esta obra en unas cuantas semanas antes de entregarla para su traslado a la Bienal de Venecia. ${ }^{26}$ En una interpretación satírica, también puede leerse como una crítica al ambiente del arte contemporáneo y sus exigencias de renovación continua, de oferta y demanda permanente, y sin descanso. El campo del arte, como se sabe, está lejos de escapar de las leyes del mercado global. De hecho, se podría decir que es una de las esferas donde más abierta y desmesuradamente se aplica la especulación económica. Si el teórico Theodor W. Adorno describía ya la forma en que la autonomía del arte y su mercantilización se

26. Basado en comunicaciones personales con algunos miembros del colectivo. 
encuentran engarzadas de manera inexcusable, ${ }^{27}$ y si algunos artistas conceptuales buscaban desmaterializar la obra, tratando de librarse del objeto como mercancía, en alguna medida Lavorare con lentezza respalda la misma lógica. Una de las ideas previas a su elaboración, pero posterior a la noticia de que serían invitados a la Bienal de Venecia, era realizar una obra imaginaria, es decir, no materializada. Conforme pasaron los días y luego de discutir y trabajar sobre el asunto, se decidió por consenso que no sería así. ${ }^{28}$ En su lugar, se optó por insertar su trabajo, tal como lo ejercen día con día, pero con los ajustes necesarios para presentarlo como obra para un suceso de esta índole, confome a las lógicas de la institución para probar cómo operaba desde dentro.

Hago una pausa en este periplo intermedial, para regresar a la dimensión subversiva de los gestos en Didi-Huberman, cuando menciona el filme Cero en conducta, del director anarquista Jean Vigo, en el que unos niños toman las sábanas a manera de bandera al sublevarse contra una institución represiva, al decir del autor, quien agrega:

Uno se rebela para manifestar su deseo de emancipación, no para exponerlo como bibelot en una vitrina, como un vestido en un desfile de moda o como una performance en una galería de arte contemporáneo. La potencia y la profundidad de los levantamientos se deben a la inocencia fundamental del gesto que las decide. ${ }^{29}$

Si se sigue el método de asociación iconológica warburgiano, resulta que la tela que se levanta y se ondea puede dirigirnos sin problemas al lienzo de la pintura. Sin embargo, el arte pictórico se enmarca precisamente en un imaginario del museo y las galerías de manera inevitable. Entonces surge la pregunta acerca de si es posible en verdad ejercer una rebelión, o al menos una crítica, al interior de la institución.

Como lo ha señalado Andrea Fraser, una de las artistas más prominentes asociadas con la crítica institucional, sería un error interpretar este tipo de operaciones, considerando que se llevan a cabo desde un lugar externo a

27. Theodor W. Adorno, Teoría estética (Madrid: Akal, 2004).

28. Esto se basa en comunicaciones personales con algunos miembros del colectivo, pero también en un documento en línea al que por consentimiento de algunos de ellos pude tener acceso. En dicho documento todos los miembros de Cráter Invertido depositaron sus ideas, quedando registradas no sólo las propuestas vertidas, sino la discusión sobre ellas y la procedencia de las mismas.

29. Didi-Huberman, Sublevaciones, 27. 


\section{DOI: https://doi.org/10.22201/iie.18703062e.2021.118.2750}

II2

MARIO ALBERTO MORALES DOMÍNGUEZ

la institución misma del arte. La institución del arte, sobre todo, no es algo que se queda en los espacios destinados a su exhibición, sino que se interioriza y se encarna en las personas, es todo un campo social..$^{30}$ Lavorare con lentezza consiste en cierta forma en un ejercicio de sobrerrepresentación o sobreidentificación de una obra de arte, puesto que es una especie de lienzo, en el que aquellos fanáticos de perseguir la mano del artista que ha osado colocar su pulso sobre la obra, emprenderían una búsqueda que sería infinita. La operación crítica va directamente sobre uno de los pilares del trabajo o labor artística que por tradición han definido no sólo la pintura, sino la planeación proyectual en general: el boceto a mano. No nos engañemos, una vez invitados a un evento como la Bienal de Venecia, la trampa estaba tendida. No había forma de escapar a la absorción de esta obra por parte de la institución del arte que se alimenta de la sangre tanto de los expertos como de los inexpertos en la materia. Pero vayamos más lejos, desde el momento en que estos individuos decidieron estudiar arte aceptaron de manera implícita los riesgos de asumirse como artistas con todo el encargo social que ello conlleva. Habría que agregar con Fraser que, si es verdad que hablar de un "afuera" de la institución del arte es una ilusión, también es una ilusión pensar que no lo hay. Y de esta última participan sobre todo quienes han estado dentro de ella desde el momento en que decidieron dedicarse a este campo. Así, una vez dentro, no queda más que asumir la aporía. Nadie es inocente.

Hacer lo máximo con lo mínimo. Los plumones, pinceles o plumas como los que se utilizaron en la composición, son algo a lo que cualquiera puede acceder. En México hay alrededor de 53 millones de personas en pobreza y 9 millones en extrema pobreza. ${ }^{31}$ De ese grado de precariedad estamos hablando. En ese sentido podría verse esta pieza en la Bienal de Venecia como una suerte de infiltración de esa realidad. No sabemos si el colectivo o sus miembros individuales estaban preparados para ello, y dejarnos asaltar por esa duda quizá sea exagerado. No se trata de una representación de las condiciones laborales de los artistas, sino de su inscripción en la obra, actuando de forma metonímica más que metafórica o simbólica. De este modo, el título de la pieza no la interpreta, así como la obra tampoco es una ilustración de su título. Entre el título y el contenido hay una distancia considerable, un salto tal

30. Andrea Fraser, "From the Critique of Institutions to an Institution of Critique", Artforum 44, núm. I (2005): 278-285.

3I. Datos obtenidos de la Comisión Nacional de Evaluación de la Política de Desarrollo Social Coneval, consultado el Io de diciembre de 20I8, en https://www.coneval.org.mx/Medicion/Paginas/PobrezaInicio.aspx. 


\section{DOI: https://doi.org/10.22201/iie.18703062e.2021.118.2750}

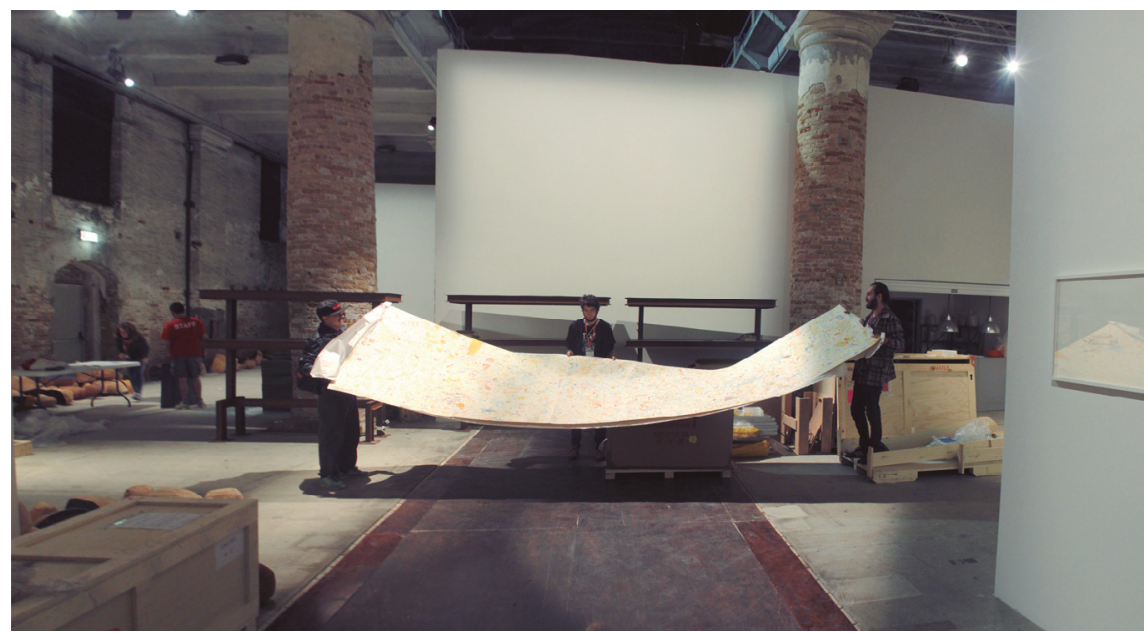

3. Cooperativa Cráter Invertido, Montaje de la obra Lavorare con lentezza, 2015, Bienal de Venecia. Cortesía del colectivo.

vez. Sin que forzosamente la economía en el empleo del color o de un papel de baja calidad y resistencia, respecto a otros materiales que pudieron haber sido usados como lienzo, haya tenido la intención de reflejar las condiciones de pobreza en México, el gesto permite un despliegue de la imaginación a partir del título. Así como Enzo Del Re aprovecha cada ejecución en vivo de su canción, la situación en que se inscribe la obra fue instrumentalizada también por el colectivo. Como mencioné antes, la imaginación es política porque se desprende de su situación a pesar de partir de ella. ${ }^{32}$ En este caso, es en el cruce entre el gesto y su situación que emerge la imaginación como potencia política. En adelante, dependerá de nosotros que le demos vida a la imagen y eso es lo que trato de hacer aquí. Habitar la contradicción, como decía una de las frases citadas de la obra, es algo que se ha vuelto común no solamente en los ambientes artísticos, sino en todo el mundo. En el siguiente y último apartado nos extenderemos sobre las potencias políticas de la obra, tomando en cuenta las posiciones ambivalentes en que se enmarca. Por lo pronto, Lavorare con lentezza, si nos apegamos no solamente a este título, sino también a la forma en que fue realizada y todo el contexto circunstancial alrededor de ella,

32. Mario Morales, Sandro Brito y Jazael Olguín, eds., Imaginación política. Encuentro Internacional (Ciudad de México: Cráter Invertido / PostFilia / Neri Barranco, 2019). 


\section{DOI: https://doi.org/10.22201/iie.18703062e.2021.118.2750}

II4

MARIO ALBERTO MORALES DOMÍNGUEZ

nos llevaría, cuando menos, a preguntarnos cuestiones sobre la labor artística como un trabajo más dentro de los regímenes actuales, pero esta vez vinculada con la estética en el sentido de sensibilidades, cuerpos y ritmos (fig. 3).

\section{Politica-recepción}

Después de este recorrido por las referencias y afinidades implicadas en la gestación de la pieza, desde la elección de formato, nombre y técnica, volvamos a una de las preguntas detonantes y transversales: ¿Cómo se posiciona políticamente esta obra? De acuerdo con la lectura de Sol Henaro, "el resultado no fue convincente porque falló en dar cuenta de los intercambios de colaboración que caracterizan sus procesos creativos." 33 Sin embargo, como señalé arriba, lo que observamos en la pieza es justo lo contrario, una muestra bastante precisa de los procesos creativos, productivos y autorreflexivos que han atravesado al colectivo. Habría una lectura, probablemente, hacia el interior de quienes han compartido estos procesos, a la cual es difícil acceder si no los conocemos o no hemos participado de ellos. ${ }^{34}$ Cuauhtémoc Medina, por su parte, señaló alguna vez este inconveniente:

Yo creo que hay cosas muy interesantes que han pasado en Cráter Invertido y, sin embargo, ver la gama de contradicciones y fallas de lo que mandaron a Venecia me parece un síntoma de que el año pasado se perdieron más en lo de los 43, y lo digo con mucho dolor, pero también como un señalamiento de algo que no entiendo, hicieron un dibujo que básicamente eran los doodles que hacían cuando hablaban y lo pusieron ahí. Y honestamente lo más incendiario que había en esa pieza

33. "The result wasn't convincing because it failed to account for the collaborative exchanges that characterise their creative processes", en Sol Henaro, "Cooperativa Cráter Invertido: A Binding Latency”, Afterall, vol. 4I (2016): II6 (la traducción es mía).

34. En este sentido valdría la pena señalar una cierta "tradición" del dibujo que ha caracterizado no sólo al colectivo sino a algunos de sus miembros de manera individual, que precede incluso a la conformación de Cráter Invertido. Por ejemplo, el grupo de trabajo denominado "Siempre otra vez" es anterior al nacimiento del colectivo, y algunos de sus fundadores participaron en la formación como artistas de otros miembros del colectivo. Además, ya constituidos como Cráter Invertido, han elegido nombres como "Vacaciones de trabajo" o "Seminario imaginario" para ejercer la práctica del dibujo, ya sea para cómics, fanzines, animación, graffiti, entre otros formatos, tanto dentro del colectivo como en subgrupos a partir de éste, proyectos alternos o para producir obra individual. 
era el extinguidor que colgaba al lado en la Bienal, y hay un cierto nivel en donde yo tiendo a tener un afecto por el artefacto, que me parece que no acompañar del artefacto una producción de subjetividad, es algo que puede llegar a seńalar la falla de la producción de subjetividad. Pero como no he estado siguiendo qué están haciendo, a lo mejor ya se transformaron en algo que es distinto a lo que pasaba en octubre del ańo pasado, que parecía que había alguna sustancia, y puede ser que se haga una denuncia del error de esta discusión. Claramente hay un problema que es parte de la situación en este momento, y es la gama de dificultades que emergen de querer personificar una contrainstitución, pero no hay nada que yo encuentre negativo en que la gente se meta en problemas, históricamente ha sido un modo muy natural de hacer las cosas, bien, mal y peor, entonces está bien que alguien lo intente. Ahora, lo que no encuentro satisfactorio es que a diferencia de otras cosas que han hecho en el pasado, individual o colectivamente, pueda haber un síntoma en la debilidad de esta intervención [en Venecia] que fue extremadamente contradictoria. Fue llevada a cabo a través de una invitación oficial y en donde aparecían ahí para extender internacionalmente una serie de chistes parroquiales, puede que haya algo muy profundo ahí, pero honestamente yo no lo vi, y me hizo pensar que podía haber el peligro de que pasáramos de un Cráter Invertido a un Cráter extinguido, por el extinguidor que estaba cercano. Espero equivocarme. ${ }^{35}$

Como se ha demostrado, es evidente que no haría falta más que una lectura iconográfica básica para que la pieza nos hablara lo suficiente, pero no nos conformaremos con ello. En efecto, el caso de los 43 estudiantes desaparecidos entre el 26 y el 27 de septiembre de 2014 en Iguala, Guerrero, ha atravesado al colectivo, y está presente en la obra a manera de pequeñas referencias a la figura de Julio César Mondragón, cuyo rostro fuera desollado por causas y razones dudosas. ${ }^{36}$ Pero, de hecho lo que se muestra en la obra no es una etapa diferente del colectivo, sino una condensación y exhibición de su proceso creativo sin filtros ni ornamentos. Quizás es esto lo que puede llegar a desconcertar. La producción del dibujo conlleva la de la subjetividad de los

35. Pamela Ballesteros, "Relatoría III Conversatorio: La posibilidad de lo político en el arte contemporáneo", conversatorio con Cuauhtémoc Medina, Antonio Vega Macotela, Salvador Gallardo Cabrera y Brenda Caro Cocotle como moderadora, GASTV, 30 de junio de 2015 , en http://gastv.mx/relatoria-conversatorio-iii-la-posibilidad-de-lo-politico-en-el-arte-contemporaneo/ consultado el 25 de febrero de 202I.

36. Para una crónica detallada y cercana al caso véase Diana del Ángel, Procesos de la noche (México: Almadía / Fondo Ventura, 20I7). 


\section{DOI: https://doi.org/10.22201/iie.18703062e.2021.118.2750}

participantes. No se muestra una careta concluyente o inequívoca, por el contrario, estamos frente a un boceto crudo, resuelto con una suerte de descaro, pero también de complicidad hacia quien comparte varias de sus situaciones, al pertenecer al ámbito privilegiado del arte en un contexto difícil y complicado como el mexicano. Como ya lo mencioné antes, no se trata de personificar una contrainstitucionalidad, sino de asumir las contradicciones que trae consigo la afiliación a la rama institucional del arte. Es cierto, hay una debilidad en esta pieza, la cual caracteriza no sólo al arte mexicano sino a la mayoría de los habitantes de este país. La pieza se muestra como una especie de precariedad: de instrumentos, de técnicas, de colores, pero esa misma condición, lo sabemos, es una de las características más comunes del trabajo actual en todos los ámbitos, y quizá más marcada en ciertas esferas del arte alejadas de los grandes mercados. Una vez más, la obra logra atravesar una serie de temas que nos conciernen políticamente.

Lo importante no es lo que dicen o tratan de decir los integrantes de Cráter Invertido por medio de la pieza, de todas esas consignas, frases, mensajes o expresiones tanto literales como metafóricas mediante dibujos desesperados, distorsionados, obsesivos, sádicos, humorísticos, entre otros elementos - $\mathrm{y}$ no pretendo afirmar que mi interpretación tenga alguna validez por encima de ello- , sino el espacio que se abrió para decir algo, las manos que intervinieron, el tiempo que se llevó para realizarla y gestionarla, las subjetividades que quedaron ahí plasmadas, todo aquello que, por muy austero que sea, no deja de contener un entramado de historias, contextos, conflictos, alianzas y cruces de todo lo que la conforma. Respecto de los comentarios de Henaro y Medina, es posible que se esperara demasiado del colectivo al pedirles "representar" a México en la Bienal de Venecia, y que el encargo los haya superado. Pero es ahí donde de nuevo el gesto adquiere valor, pues pese a todo, no ofrecieron un discurso político acabado o desde una postura definitiva y única, sino que, al contrario, decidieron dar cabida a todo tipo de expresiones multiformes. Este gesto, al situarse antes que la articulación ordenada de cualquier postura, se quedó sólo en el ámbito intermedio entre la aceptación y el rechazo a la representación. Así, lo que puede criticarse como una ambigüedad o falta de proclamación política, desde otro punto de vista puede verse como una táctica de desmarcaje. Las querellas personales se extienden o se llevan a lo internacional, toda vez que no hemos resuelto ni siquiera lo inmediato. Como se puede leer en alguna de las publicaciones relativas a los proyectos colectivos que ahí suceden: 
Somos las asimilaciones de un proceso/inacabado de características imaginarias que se han impuesto sobre nuestros cuerpos los cuales emergen desde una interminable disputa a través de la historia (de conquistas, esclavitudes, migraciones, acercamientos y despojos en todos los aspectos de la vida) e incorporamos nuestras historias dentro de los imaginarios más cercanos, desde los cuales construimos para entendernos y realizarnos como imágenes de nosotrxs mismxs. ${ }^{37}$

Cráter Invertido, además de un espacio de trabajo, es también una apertura en el tiempo, donde las personas se dan cita, muchas veces dejando de lado sus labores remuneradas, a pesar de que muchas de ellas puedan dedicarse al arte. En este sistema de flexibilidad laboral, donde el trabajo ha terminado por abarcar nuestra vida entera, de pronto un espacio geográfico y temporal como éste se convierte en una excepción. Pero Cráter Invertido es sólo un ejemplo de una forma de operar, es uno entre muchos grupos. Y no tendría por qué ser tomado como algo más. Ciertamente va a extinguirse, pues depende de muchos factores que van más allá de cualquiera de las intenciones de sus miembros. Y surgirán otros grupos e iniciativas de quienes pertenecen ahora a este grupo, o a otros. Sin embargo, eso no quiere decir que abordar el caso no nos pueda decir mucho sobre la potencia de la imagen y la imaginación políticas en una obra, sobre lo que podemos ser y llegar a ser cuando se entrelaza una serie de elementos, ya sea por casualidad o por voluntad, y sobre lo que esto podría significar para configurar alternativas o futuros distintos.

Luego de cinco años de trabajo continuo, el colectivo que siempre ha asumido en forma de asamblea la toma de sus decisiones en conjunto, presenta por medio de la obra Lavorare con lentezza una ilustración de su propio proceso político interno. En otras palabras, esta obra podría considerarse como parte de una tendencia de arte político, pero no porque sea una especie de denuncia, reclamo o protesta hacia alguna instancia externa ya sea del mundo del arte o de la política global o nacional de algún país. Más bien se trata de una

37. Fragmento de un texto curatorial impreso de modo informal a manera de fanzine para la exposición "Don't Stop Till you Get Enough", llevada a cabo en una de las habitaciones de Cráter Invertido durante agosto y septiembre de 20I7. La exposición giraba en torno a la figura de Michael Jackson, jugando con diversas apropiaciones de su imagen en diferentes formatos, pero siempre partiendo del dibujo a mano alzada. Los artistas participantes fueron Al Curiel, Fermín Díaz aka Sugar, Ana Sofía Becerra, Karen Cheirif y Rodrigo Treviño. El texto está firmado con el seudónimo de Krisis Zapata. Véase Krisis Zapata, “Don't Stop Till you Get Enough" / Exposición y venta de dibujo / Cráter Invertido, Muestra de dibujo (2017): 4. 


\section{DOI: https://doi.org/10.22201/iie.18703062e.2021.118.2750}

II8

MARIO ALBERTO MORALES DOMÍNGUEZ

autorreflexión sobre el proceso de creación colectivo y las políticas intersubjetivas que ahí se ven implicadas. En general, si el arte de Cráter Invertido hasta la fecha ha sido catalogado como político, no es sino porque siempre se han preguntado sobre sus propias condiciones de trabajo como artistas y porque en este cuestionamiento han incluido a la sociedad que los rodea, ya sea saliendo a la calle o abriendo sus puertas para el diálogo y la producción en conjunto. Lo que vemos en esta obra se podría perfectamente identificar como una asamblea materializada. Se trata de una gran cantidad de voces que se cruzan unas con otras, que se lanzan desde diferentes lugares y en distinto sentido, de tal manera que en el centro se encuentran en una suerte de caos particular donde al final no tienen otra opción más que perderse entre la multitud de expresiones que lo pueblan. Sin embargo, justo el hecho de que el sentido de los dibujos obedezca a la organización de una mesa asamblearia, en círculo alrededor de una mesa, nos habla de una política: dar lugar a todos los gestos, sin importar de dónde provengan. Quizá como un esfuerzo voluntario, aunque no por eso fácil ni siempre placentero, para desencadenar la creación.

No es casualidad que este grupo de artistas haya elegido la asamblea como forma de regulación, pues parece ser la única opción para disolver jerarquías y órdenes de unos sobre los otros. Recordemos que, desde la perspectiva del escritor anarquista Murray Bookchin ${ }^{38}$ siempre hay una dimensión social y personal en las instituciones que estructuran la vida cotidiana y las relaciones interpersonales. En otras palabras, ninguna forma de organización puede aislarse de aquello que ordena. En este caso, la asamblea de Cráter Invertido surge en un contexto hostil, aquel que ha sido forjado por el Estado mexicano; un ambiente casi de barbarie, lleno de atrocidad e impunidad. La asamblea surge, así, como una especie de refugio, donde las relaciones de poder, tan amañadas e incluso sádicas en este país, parecen suspenderse aunque sea por breves momentos y en pequeños espacios. Podemos estar seguros, dice Bookchin, de que este tipo de sublevaciones nacen de manera espontánea y por ello resultan tan sorpresivas ante las figuras de autoridad. Si comprendemos Lavorare con lentezza como una asamblea materializada, tal vez podríamos captar mejor su ambigua y crítica relación con el mundo del arte institucional.

Por otra parte, la asamblea no está libre de conflictos. Con todo y sus querellas, este proceso quedó grabado en la pieza, hayan o no querido hacerlo sus participantes. Por ejemplo, en la obra se encuentran algunos mensajes directos

38. Murray Bookchin, Post-Scarcity Anarchism (Edimburgo: AK Press, 2004). 
de algunos miembros a otros, o de alguno en particular al resto del colectivo. Hay denuncias, protestas, paráfrasis o satirizaciones de parte de los integrantes del grupo hacia el papel que cumple Cráter Invertido no sólo en sus vidas sino también en la escena del arte en México. Todo esto se encuentra en el dibujo, aunque para algunos pueda resultar una manera un tanto críptica de hacerlo. Se trata de una especie de códice por interpretar en cada ocasión desde diferentes lugares y, en ocasiones, es necesario saber algo sobre lo que sucede al interior del grupo para poder acceder a ello. Las claves para descifrar estos mensajes no podrían exponerse aquí por diversas razones, porque son muy personales y no sería ético, y por lo mismo son de muy difícil acceso; o quizás porque a nadie le interesarían. Pero, más allá de ello, lo relevante es mostrar que, a pesar de las diferencias, hay afinidades, complicidades, complementariedades y, en general, formas de cooperación y co-creación que se podrían rastrear, una vez más, en las formas de organización relativas al anarquismo, la subversión y lo que se ha llamado desde ese lugar como "afinidad". 39

No hace falta un gran recorrido para notar que la asamblea es también una especie de montaje, uno de los temas más importantes en la obra de Didi-Huberman. ${ }^{40}$ En español el término "asamblea" tiene conexiones etimológicas y fonéticas evidentes con el término "ensamblaje", mientras que en otros idiomas como el francés y el inglés el término, pronunciado de modo distinto, pero literalmente compartido, "asemblage", puede hacer referencia tanto a la reunión de personas como de objetos o elementos cualquiera. ${ }^{41}$ Más aún, en un artículo reciente, Luis Ignacio García ha retomado el "pensamiento en imágenes" de Didi-Huberman para articular una propuesta del montaje como apuesta

39. Los miembros de Cráter Invertido definen sus prácticas y sus diferentes subdivisiones y formas de organización por grupos de afinidad. Véase Cráter Invertido, "Conversatorio a cargo de Cráter Invertido", entrevista con Diego Teo y Rodrigo Treviño, TEOR/éTica, Costa Rica, 9 de abril de 20I6, en https://www.youtube.com/watch?v=HqpSpONI-zQ\&t=62os, consultado el 25 de febrero de $202 \mathrm{I}$.

40. Sobre todo en sus trabajos sobre Aby Warburg ya citados aquí como La imagen superviviente o Atlas ¿cómo llevar el mundo a cuestas?, pero para este tema también sería importante remitirse a Cuando las imágenes toman posición (Madrid: Antonio Machado Libros, 2008) o Remontajes del tiempo padecido. El ojo de la historia 2 (Buenos Aires: Editorial Biblios, 2015).

4I. En especial en el epílogo del libro de Craig Buckley, Graphic Assembly: Montage, Media, and Experimental Architecture in the Ig6os (Mineápolis: University of Minnesota Press, 2018), titulado "Image as Assemblage", se retoma el término, en la forma en que fue propuesto por Gilles Deleuze y Félix Guattari, para hablar de las potencialidades políticas de las técnicas de montaje en diferentes prácticas artísticas del siglo xx. 


\section{DOI: https://doi.org/10.22201/iie.18703062e.2021.118.2750}

$\mathrm{I} 2 \mathrm{O}$

MARIO ALBERTO MORALES DOMÍNGUEZ

estético-política sobre la comunidad. ${ }^{42}$ Es cierto que, como lo he mencionado antes, no hay una postura clara, definida o definitiva que se pueda extraer por medio de la sola imagen de la pieza. Pero, por otro lado, es posible que se trate más bien de una muestra de formas emergentes de hacer política, que dejan atrás las clásicas posturas militantes como las entendíamos hasta ahora para dar paso a nuevas concepciones de la comunidad como una especie de montaje permanente.

En México, hoy día, hay un gran número de espacios independientes. Las labores de investigación y documentación de estos espacios las están realizando personas jóvenes e inscritas en la escena emergente como Tamara Ibarra o Sandra Sánchez, al tiempo que se rescata y documenta a la generación de los grupos y los espacios de las últimas tres décadas del siglo pasado en México. ${ }^{43}$ En este contexto se hace necesario teorizar acerca de estos espacios, saber cuál es su lógica, qué significa que surja este tipo de espacios en un país y en un momento histórico como el nuestro. En "Ensayo: 1994, de Cráter Invertido, una indagación al presente de México", la filósofa y curadora Helena Chávez Mac Gregor realiza una aproximación al trabajo del colectivo desde los términos de flujos y cartografías de Gilles Deleuze. ${ }^{44}$ Tamara Ibarra, por su parte, comenzó su investigación gracias al desarrollo de un proyecto llamado "Tomar la ola. Movimiento de los Espacios Independientes en México 2009-2015", título que hace referencia a las figuras del surfista y del nadador aludidas por Deleuze. ${ }^{45}$ Estas contribu-

42. Luis Ignacio García, "La comunidad en montaje: Georges Didi-Huberman y la política de las imágenes", Aisthesis, núm. 6I (2017): 93-II7.

43. Específicamente sobre Cráter Invertido, además de los textos que ellos mismos publican, se pueden encontrar referencias en diversos escritos de divulgación. Véase Patricia Martín, "Espacios artísticos independientes: Cráter Invertido", El Financiero, 13 de agosto de 2015, consultado el 25 de febrero de 202I, en http://www.elfinanciero.com.mx/opinion/espacios-artisticos-independientes-crater-invertido.html; Alejandra Ortiz Castańares, "Colectivo mexicano traslada su arte alternativo a la Bienal de Venecia”, La Jornada, 27 de junio de 20I5, consultado el 25 de febrero de 202I, en http://www.jornada.unam.mx/2015/06/27/cultura/a07nicul; Fólder ooI, "La imaginación radical de Cráter invertido", Post-Filia, I3 de marzo de 2019, consultado el 25 de febrero de 202I, en https://postfilia.com/2019/03/13/la-imaginacion-radical-de-crater-invertido/; o haciendo un recuento de la escena local, Sandra Sánchez, "Formatos expositivos...", https://twitter.com/YEImagmx; entre otros.

44. Helena Chávez Mac Gregor, "Ensayo: 1994, de Cráter Invertido, una indagación al presente de México", Código, núm. 8o (20I4), consultado el 25 de febrero de 202I, en http://www. revistacodigo.com/1994-de-crater-invertido-una-indagacion-al-presente-de-mexico/.

45. Tamara Ibarra explicó esto en la presentación del proyecto llevada a cabo el I3 de enero de 2016 en SOMA. 
ciones nos ayudan a ver más allá de un simple juicio sobre una obra, contribuyen a un discernimiento de un alcance más amplio que toma en cuenta lo social y lo político. La obra, en todo caso, se presenta como un acceso, un tamiz hacia la intersubjetividad, la colectividad y la asamblea en un contexto determinado, así como la micropolítica y los afectos conscientes e inconscientes que en él se dirimen. En ese sentido, la noción de "sujeto" que en el caso que me ocupa podría plantearse no se referiría a las personas, sean miembros o no de uno u otro colectivo, sino al sujeto político y el cruce de flujos de todo tipo que lo atraviesan en momentos específicos.

Desde la mirada del montaje, de la mano de Didi-Huberman, y de los demás temas que he puesto sobre la mesa, se podrían identificar estas formas de operar colectiva y políticamente con lo que hace poco Nick Montgomery y carla bergman ${ }^{46}$ han llamado "militancia alegre" ${ }^{47}$ Frente a un radicalismo rígido, que se basaría en una búsqueda de pureza o dogmatismo ideológico, estos autores proponen un tipo de militancia abierta basada en la escucha, la curiosidad y la experimentación, acompañada de otro tipo de teoría: una que sea participativa y no como directriz; una no acabada, sino siempre en proceso. Cuando se usa la palabra "alegre", en este contexto, se remite al filósofo neerlandés del siglo Xviı Baruch Spinoza. La alegría, según este autor, se refiere al aumento de la potencia de actuar, ${ }^{48}$ de tal manera que la militancia alegre la toman Montgomery y bergman como una colectividad de gente que se potencia mutuamente. Se trata de un tipo de comunidad que se forma no en la imposición de una serie de reglas ni mucho menos aún en la autoridad de unos sobre otros, sino que, con mucha influencia de la tradición anarquista, lo que se plantean son organizaciones descentralizadas y flexibles, basadas en afinidad y siempre en recomposición; abiertas al cambio y a la renovación.

Como señalé arriba, Cráter Invertido no está solo sino que está en un contexto. No es sino a partir de unas ciertas condiciones sociales y en el marco de determinadas prácticas institucionales del arte que este tipo de espacios pueden surgir y desarrollarse. Se trata de una suerte de laboratorios de la imaginación, lugares donde se abre la posibilidad para la emergencia de lo que Cornelius Castoriadis identificó como "imaginación radical”. ${ }^{49}$ Recordemos que para este

46. El nombre y apellido de esta autora están en minúsculas en el original.

47. Nick Montgomery y carla bergman, Joyful Militancy. Building Resistance in Toxic Times (Edimburgo: AK Press, 2017).

48. Baruch Spinoza, Etica demostrada según el orden geométrico (Madrid: Tecnos, 2007).

49. Cornelius Castoriadis, La institución imaginaria de la sociedad (Buenos Aires: Tusquets, 2007). 
DOI: https://doi.org/10.22201/iie.18703062e.2021.118.2750

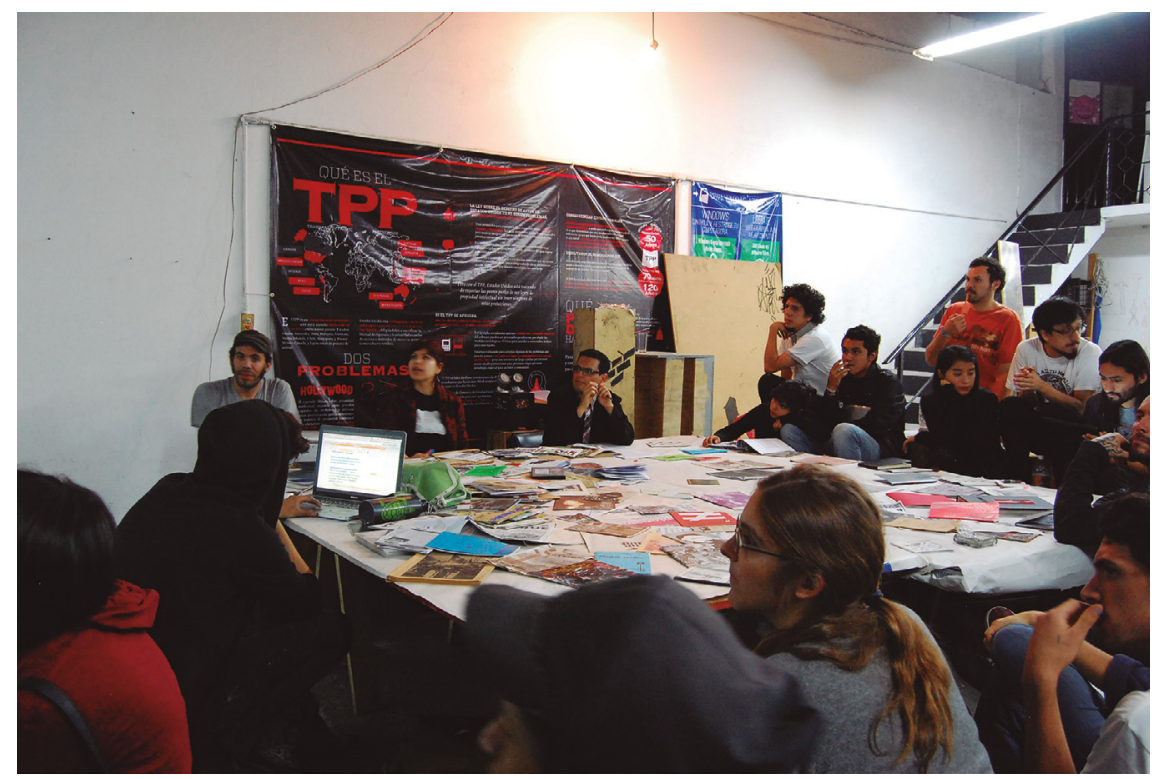

4. Asamblea de Cráter Invertido junto con otros colectivos. Fotografía de Satanismo Crítico, tomada de: https://666ismocritico.files.wordpress.com/2013/06/dsc_0515.jpg

autor la sociedad es imaginaria, es decir que se mantiene viva a partir de que crea a los individuos que necesita mediante operaciones en la imaginación. $\mathrm{Y}$, sin embargo, dentro de este entramado de significaciones imaginarias hace falta también una imaginación radical que le dé la posibilidad de renovarse al mismo tiempo en un proceso permanente. En tiempo reciente, Max Haiven y Alex Khasnabish han rescatado este concepto al explicar la forma como operan ciertas prácticas artísticas y movimientos sociales, y también para convocar a ella..$^{\circ}$ Siguiendo a Castoriadis, para estos autores la imaginación radical es una potencialidad inefable y dinámica que está en la base de toda forma social. Sin embargo, en la globalización esta fuerza social de la imaginación tiene la posibilidad de volverse ilimitada tanto para hacer emerger luchas justas como movimientos reaccionarios. Así, para no caer en ambigüedades, falsas promesas o movimientos de opresión, la imaginación ha de engarzarse con alguna

50. Max Haiven y Alex Khasnabish, The Radical Imagination: Social Movement Research in the Age of Austerity (Londres: Zed Books, 2014). 
lucha específica y con condiciones muy precisas para tener efectos. ${ }^{\text {II }} \mathrm{Tal}$ es, se podría decir, lo que se intentó con la elaboración de Lavorare con lentezza, y tal es lo que, en todo caso, este mismo texto intenta volver a poner sobre la mesa. Lo cual no quiere decir que sea un intento perfecto, sin fallas, sin fisuras o sin críticas posibles, pero sí que se trata de un proceso que, en última instancia, involucra también a todas estas respuestas en su curso (fig. 4).

\section{Conclusión}

Un acercamiento como éste no se pudo haber realizado sin que hubiera un involucramiento personal con el colectivo, a partir del cual se tomaron diversas opiniones citadas en el texto, pero también se manifiesta como aquellas influencias recogidas en conjunto y expuestas aquí. En primer lugar, este trabajo se ha visto atravesado por un intento de aproximación a la obra Lavorare con lentezza desde un punto de vista particular, como un esfuerzo político de interpretación que requirió la construcción de un vocabulario, un modo de operación y un andamiaje conceptual en correspondencia con ello. Así, en un primer momento no sólo traté de dar cuenta del aspecto iconográfico de la pieza, al describir el contenido del dibujo, sino sobre todo iconológico, que se deriva de los trazos, reflexiones políticas acerca del sentido del gesto, la huella, la supervivencia y la imagen como atlas. A partir de esto, me queda claro que la imagen puede abordarse al menos de dos maneras, como supervivencia o huella, y como representación o doble. Del mismo modo, he llevado este tipo de ejercicio de observación al lenguaje en relación con el título de la obra, sin buscar extraer significado alguno, sino más bien las derivaciones vinculadas con las prácticas y el contexto en que se inserta la pieza. Por último, he planteado que este entramado compuesto en torno a la pieza forma parte de una teoría en construcción no separada de su objeto y del contexto en que se concibe. Así, todos y cada uno de los pasajes por los que he transitado en este texto, podrían verse como algunos trazos más que se unen a los que se observan en la pieza, esta vez no sólo a manera de gráficos, sino como gestos conceptuales, nuevas extensiones de la obra que forman parte de la construcción de una imaginación política en proceso.

5I. Max Haiven y Alex Khasnabish, "What is Radical Imagination? A Special Issue", Affinities: A Journal of Radical Theory, Culture, and Action 4, núm. 2 (2010): I-XXXVII. 


\section{DOI: https://doi.org/10.22201/iie.18703062e.2021.118.2750}

$\mathrm{I} 24$

MARIO ALBERTO MORALES DOMÍNGUEZ

El ejercicio de lectura que he realizado tuvo como eje rector dejar que la obra me condujera hacia otros lugares, pero a cada paso desde una posición determinada. De este modo, al asumir que cada detalle de la pieza puede llevar a una elaboración interminable, trabajé con una especie de asociación libre que en su despliegue fue tejiendo un sentido. El apartado "Gestos-creación" me sirvió como soporte para que la situación concreta de la pieza en su contexto de producción se pudiera apreciar como una apuesta política que involucra la composición de la imagen y el uso de la imaginación. De esta manera, los elementos iconográficos se mezclaron con cuestiones relativas a la vida cotidiana de los miembros del colectivo, sus afiliaciones institucionales, reflexiones intra y extragrupales, decisiones, organización, dinámicas, contexto, influencias y referencias, así como con una lectura ajena a posteriori que intenta recomponer las piezas. El gesto político no está solamente en la creación de la obra que, como señalé, tiene que ver con la pluralidad de trazos, subjetividades, voces, vidas. No termina ahí, sino que se extiende a su lectura. Ésta puede detenerse en observarla como un capricho malogrado. Puede perderse en una crítica severa hacia la falla en haber desaprovechado la posición de poder que les dio la visibilidad. Pero, por el contrario, en este texto intenté participar desde la observación de las potencialidades de la obra, al explicitar este modo de acercamiento para comprender cómo esta noción de imaginación política que he rastreado no puede sino partir de la inmanencia del gesto y sólo desde ahí poder extenderse a otras dimensiones. La obra como gesto superviviente que se presenta ante la mirada como un atlas a ser explorado, es parte de los rasgos de una imaginación colectiva y en composición permanente.

Como lo describí en el apartado "Situación-exhibición", tanto el colectivo Cráter Invertido, como yo, y muy probablemente quien lea este texto, estamos inmersos en condiciones materiales específicas que, en este caso, involucran dinámicas de trabajo, competencia, efectividad y precariedad, cuando menos. El trabajo mostró cómo el colectivo Cráter Invertido trata de asumir críticamente esta responsabilidad para con la institución del arte en su práctica radical del boceto y todo lo que tiene que ver con éste cuando se realiza de manera colectiva. Pero también se ha de tomar como un ejercicio de autorreflexión teórica, cruzando todos los niveles que he descrito a lo largo de este texto. Las frases o palabras sueltas que se leen en la pieza, así como las alusiones y menciones, tanto históricas como culturales, que se encuentran ahí, dan cuenta de un esfuerzo de expresión que va más allá de la comunicación directa de un mensaje. Se trata de gestos que por medio del uso de caracteres textuales nos lanzan 
a especulaciones teóricas encarnadas en la historia del arte y sus debates internos, tales como la autonomía versus la mercantilización, la crítica institucional desde su interior y las potencialidades de lo colectivo. Con la forma del gesto, en el sentido en que lo expuse en el primer apartado, cuando éste se coloca en su situación en torno al campo problemático del arte institucional, adquiere una dimensión crítica y política. Así, la operación no se queda en un mero dar cuenta de la obra y sus sentidos inmanentes, sino que trata de extraer de ellos una mirada y una conjetura acerca de lo que podría significar una imaginación política que responde a su situación. De pronto la Bienal de Venecia, cuando se pone en contraste directo con la producción de aquellos gestos en un formato tan rústico como unos trazos sobre un papel y en un contexto como el de México, nos da la oportunidad de preguntarnos sobre qué tipo de política se está proponiendo. Hizo falta, por ello, pasar de la situación a la conceptualización, ya que es en el ámbito de las discusiones y propuestas teóricas donde una obra, más allá de sus efectos inmediatos, puede llegar a decirnos algo.

Lo que aquí se encuentra es una voz y una exposición más de la obra, dispuesta para ser retomada en diversos sentidos; abierta no sólo a la crítica rígida, sino sobre todo a que desde la afinidad pueda dar cabida a nuevas formas de imaginar tanto la obra de arte como sus potencialidades. En el apartado "Política-recepción" quise dejar huella de las formas en que hoy y con base en ciertas prácticas aún es posible pensar, imaginar, reunirse, organizarse y producir desde otros lugares. En un contexto como el nuestro, de hecho, hace falta todavía mucho por construir en conjunto. En ese sentido, me remito al contexto de la obra en la esfera del arte en México, al citar a críticos y curadores de arte actuales, para después rescatar planteamientos vinculados con el pensamiento político contemporáneo, desde una apreciación muy general del sentido político de la pieza, hasta categorías que están siendo desarrolladas y que responden a las mismas preocupaciones en las que se enmarcan no sólo esta obra, sino las prácticas del colectivo en cuestión y de otros que comparten su contexto. Busqué dar cuenta de la forma como es posible responder con ejercicios concretos como la asamblea, y su materialización en Lavorare con lentezza, para propiciar y abrir paso a la militancia alegre y a la imaginación radical, dos nociones que aquí propongo como parte de un ejercicio de imaginación política en particular. Por último, más allá del caso particular tratado aquí, si se recogen algunas de las cuestiones que he planteado, como el trabajo activista, interdisciplinar, el colectivismo, la precarización laboral del artista, entre otras, estas reflexiones pueden servir para configurar nociones sobre cómo vincular el pensamiento en 
imágenes con debates estético-políticos actuales que atraviesan a otras colectividades artísticas en México.

En resumen, la noción de imaginación política que aquí se ha construido nos muestra que ésta es parte de un gesto, de una expresión de vida que queda grabada en un medio o formato. Este gesto busca su supervivencia y se basa en supervivencias, es decir, se deja un rastro que se expande a cada lectura y que se engarza con otros trazos de diferentes tipos. En este tránsito entre una detonación y una serie de conexiones incalculables, forma parte de un atlas complejo pluridimensional que debe leerse e interpretarse a su vez de múltiples maneras. En este proceso, los gestos son las marcas de este movimiento permanente de las fuerzas sociales. No hay y no puede haber una forma única de imaginación política. Ésta está siempre en relación con su situación, toma posición desde el interior de ella, utiliza los elementos, materiales y formas de operación que están a su alcance; y de ahí emerge como una fuerza que ya no pertenece a nadie en particular, sino que depende de todo aquello con lo que llegue a ligarse por vías diversas. Es decir, el proceso no sólo es colectivo, sino que depende de condiciones materiales concretas que le hacen cobrar una pluralidad de formas y vincularse con todos los ámbitos de la vida en comunidad. El proceso, en última instancia, no termina nunca, sino que todo acercamiento a la obra forma parte del mismo y se coloca, en ese sentido, en la esfera de las discusiones políticas que atañen a nuestra contemporaneidad. Es responsabilidad del espectador hacerse cargo del sentido de la obra y, en última instancia, saber observarla apelando a su propia capacidad de imaginar posibilidades sin dejar de tomar una posición política. \$ 